\title{
東京大学前史における体育
}

\author{
木村 吉次
}

\section{Physical education in the prehistoric times of the University of Tokyo}

\author{
Kichiji Kimura
}

\begin{abstract}
The purpose of this study was to investigate how physical education was introduced into schools supplying pupils for the University of Tokyo and how it was developed at those schools. The fundamental sources for the study were documents among historical materials detailing the history of the Imperial University of Tokyo and among the archives of the University of Tokyo. The findings were as follows: 1) Nanko asked the Ministry of Education to construct a playground in September 1871, and this was constructed in the following year. The Emperor Meiji visited Nanko on May 6, 1872 and viewed the playground, and Nanko seems to have had gymnastic apparatus used for the French system of military gymnastics. 2) The timetable of each class at Nanko included gymnastics for 30 minutes from 9 a.m. to 9: 30 a.m. every day, and furthermore Nanko recommended students to do other exercises and walking as extracurricular activities. Most gym teachers employed had once worked for the Primary School attached to Numazu Military Academy. They seem to have studied the French system of military gymnastics in the late Edo period. A gymnastics system similar to that of the French at the Attached School had been practiced at Nanko. 3) Although gymnastics was a supplementary subject at Kaiseigakko, and later at Tokyo Kaiseigakko, they placed stress on it and in fact regulated the timetables so that most courses had 30 minutes of gymnastics from 9: 30 a.m. to 10: 00 a.m. every day and students took gymnastic exercises under the direction of the gym teacher. At the same time provision was also made for students to wear European clothes and shoes, which were thought to be more convenient for gym and other classes. 4) The construcion of new school buildings at Kaiseigakko in August 1873 included a new playground with exercise apparatus. Judging from the blueprint, the apparatus was evidently that of the French system of military gymnastics, and designed by a person whose knowledge excelled that in textbooks of the French system: 'Shinpei-taijyutu-kyoren'. 5) The exercises displayed under the direction of the gym teachers Y. Kariya, S. Takino and K. Fukushima in the presence of the Emperor, who attended the opening ceremony at Kaiseigakko on October 9, 1873, were ko-hi (leaping), tesuri (parallel bars) and yagura (platform). 6) The discharge of gym teachers at Tokyo Kaiseigakko between January and Feburary 1877 indicated that this preceded the measure that students taking the preparatory course for the
\end{abstract}

中京大学体育学部

干 470-0393 爱知県豊田市貝津町床立 101

連絡先 木村吉次
Chukyo University, School of Health and Sport Sciences 101 Tokodachi, Kaizu-cho, Toyota, Aichi 470-0393

Correspondingauthor kkimura@sass.chukyo-u.ac.jp 
University of Tokyo, established by consolidation of Tokyo Kaiseigakko and Tokyo Igakko, were to be taught gymnastics by Taiso-denshujyo (the National Normal School of Gymnastics). 7) Kaiseigakko and Tokyo Kaiseigakko played the role of translating and publishing book about gymnastics, manufacturing gymnastic instruments such as a dumbbells, and repairing sporting goods such as rubber balls. The traditional function introducing Western Culture since the Shogunate Institute of Foreign Studies such as Tenmonnkata, Banshowagegoyoh, Yogakusho and Bansho Shirabesho could not help being expanded in the above schools so far as modern industries had scarcely developed. 8) Gymnastics was also a supplementary subject at Dai-ichi Daigakku Igakko. When it was going to construct a playground and exercise apparatus, Dai-ichiban Chugaku (formerly Nanko) helped it and allowed some staff members of Dai-ichi Daigakku Igakko to inspect the playground and apparatus at Dai-ichiban Chugaku and lent them the blueprint. Igakko (formerly Dai-ichi Daigakku Igakko) had gym teachers concurrently holding similar positions at Kaiseigakko. Thus the successors of Nanko which had been pioneers in introducing gymnastics into modern schools in Japan had often helped those of Tohko (the Medical School).

\section{Key words : Nanko, Kaiseigakko, gymnastics, the Attached Primary School to Numazu Military School, French system of military gymnastics}

(Japan J. Phys. Educ. Hlth. Sport Sci. 49: 1-18, January, 2004)

\section{キーワード：南校, 体操, 沼津兵学校附属小学校, フランス式軍隊体操}

\section{I 問題の所在}

日本における学校体育の成立に関する研究は， 日本近代体育史研究の主要な課題であったため今 村嘉雄 ${ }^{11}$ ，岸野雄三 ${ }^{2)}$ ，大場一義 ${ }^{3)}$ ，能勢修一 ${ }^{4)}$, 木下秀明 ${ }^{5)}$ ，大久保英哲 ${ }^{6)}$ らによって取り組まれ， その成立過程はかなり明らかにされてきた。しか しながら，それらの研究に少し立ち入って検討し てみるとき，究明されべき課題がなお残されてい るように思われる。それは，明治期の教育に関す る一次史料である文部省関係史料が関東大震災に よって消失してしまったことによるところが大き いと思われる。とりわけ，まだ十分に解明されて いないものとしては, 体操伝習所設置以前の学校 における体育の採用と実施の状況の問題がある.

この時期に学校体育を採用し, 実施した学校と して注目されるのは東京大学とその前身校であ る. 東京大学は，二つの系譜の学校が統合されて 成立したものであるすなおち，天文方（1684
年）・蛮書和解御用（1811 年） - 洋学所（1855 年）・蕃書調所（1857 年）といった系譜に連な る大学南校（1870年 12 月）は，南校（1871年 7 月）一第一大学区第一番中学（1872年 8 月）一開 成学校（1873 年 4 月）一東京開成学校（1874 年 5 月）一東京大学（1877年 4 月）と変わり, もう一 方の種痘所（1858年）・西洋医学所（1861 年） の系譜に属する大学東校（1869 年 12 月）も，東 校（1871 年 7 月）一第一大学区医学校（1872 年 8 月）一東京医学校（1874 年 5 月）一東京大学 (1877 年 4 月）とめまぐるしく変わった ${ }^{7)}$ 。この ように東京大学は，この二つの系譜に属する学校 を統合して成立したものであったが，体育の立場 から見て重要なのは体操伝習所による近代学校体 育が本格的に創出される以前に，東京大学がその 前身校の時代から独自に体育の導入を図り, 実施 していたことである.

これについては上記の研究者らによっても断片 的にはふれられているが，必ずしも十分明らかに されたとは言い難い. 永田進の研究は, 最も早く に東京大学前史における体育にふれたものとして 注目される. 永田は, 福島惟成等 4 名の体操教員 
が沼津兵学校付属小学校の体操教員だったことを 明らかにしていた ${ }^{8)}$. そして, 今村嘉雄も, 早く から，度々東京大学前史における体育をとりあげ ていた。はじめ，南校蔵版の「榭中体操法図」が ドイツのシュレーバー（Daniel G.M. Schreber） の著書『室内医療体操』'Aerztliche Zimmergymnastik'の付録を翻訳したものであることを 明らかにしたが9)，著書『日本体育史』では「榭 中体操法図」の成立とともに南校（大学南校と䛊 記）の運動所設置と体操の実施についても簡単に ふれていた ${ }^{10)}$. 今村はさらに，『十九世紀に於け る日本体育の研究』において「榭中体操法図」の 運動内容の分析を行い，またその普及の程度を検 討し, 考察を深めるとともに, 開成学校（南校の 誤記）から東京開成学校に至る間の体操の実施に ついて簡単な叙述を行っていた ${ }^{111}$ 。大幅な改訂を 行った『日本体育史』では『十九世紀日本体育の 研究』とほぼ同じ内容の記述を行っていたが，南 校の運動所を大学南校とする誤記はそのままにな っていた ${ }^{12)}$.

岸野雄三は, 共著『近代日本学校体育史』にお いて今村同様に「榭中体操法図」や南校の体操実 施について今村よりも簡潔にふれていた ${ }^{13)}$.また， 渡辺融が東京大学前史の体育を叙述した際にも， 東京開成学校名で南校の体操について言及してい た ${ }^{14)}$ 。大場一義も永田の研究を受け継いだかたち で, 南校の体操教師が沼津兵学校付属小学校の体 操教授方ないしは教授方手伝だった事実にもとづ いて, 沼津兵学校附属小学校の体操と南校の体操 との関連を明らかにしていた ${ }^{15)}$ 。そして，能勢修 一は『明治体育史の研究一体操伝習所を中心に一』 で「榭中体操法図」や南校の体操についてふれた のも大場のこの研究に基づいていた ${ }^{16)}$ 。枺秀明 も, 『日本体育史研究序説』において南校の運動 所, 体操の実施, 体操教員について叙述していた が，それは『東京帝国大学五十年史』や永田の研 究に基づいていた ${ }^{17)}$. しかし，木下が『東京帝国 大学五十年史』上冊に体操器械を描いた「開成学 校鳥瞰図」をとりあげ，体操器械の実際に注目さ せたことは重要である。

以上の先行研究を見たとき，それらはいずれも
『東京帝国大学五十年史』上冊中の東京大学の体 育に関する叙述に大きく依存している。この「五 十年史」は，元来体育を独立した章節にして叙述 したものではないので，南校・開成学校・東京開 成学校の学科課程の記述や運動の天覧などの記事 が主要な内容となっていた ${ }^{18)}$. それ以外では『文 部省年報』中の「東京開成学校」年報（明治 6 年） が史料として用いられていた。1984年刊の『東 京大学百年史』通史 1 は,「スポーツ・運動会」 の一節を設けて帝国大学運動会の設立と活動につ いて叙述しているが ${ }^{19)}$ ，体操に関しては「五十年 史」と同様に断片的にふれているだけである.

ところで，東京大学には，幸いにも関東大震災 による焼失を免れた史料, すなわち東京大学総合 図書館所蔵「東京帝国大学五十年史料」ならびに 東京大学大学史史料室所蔵「文部省及諸向往復文 書」等がある。これらの史料に基づいて東京大学 が成立するに至るまでの時期，すなわち東京大学 の前史における体育を考察したとき，従来得られ ている以上の知見が得られるのではないか，それ は，さらにこれまでの学校体育史研究を一歩進め ることにもなるだろうと期待される. 以下は，こ うした意図をもって上記の一次史料を用いて東京 大学前史における体育の状況を明らかにしょうと したものである.

なお，東京大学前史における体育とスポーツを 取り上げたものに渡辺融の研究 ${ }^{20)}$ があるが，こ れは課外スポーツに重点を置いたものである。ま た，上記の『東京大学百年史』通史 1 も課外のス ポーツ活動に若干ふれている ${ }^{21)}$. 本研究は，そう した学生の自主的な課外スポーツ活動の展開 ${ }^{22)}$ については，これまである程度明らかにされてい ることと，これをさらに掘り下げて研究するのに は，また別の方面に史料を求めなければならない ので，ここではひとまず考察の対象外とすること を予め断っておく.

\section{II 南校の「体操」}

\section{1. 南校の「運動場」設置}

1871 年 9 月 2 日文部省設置にともなって，「大 
学南校」は「南校」（1871年9月 5 日）と改めら れたが，それから二ヶ月程した1871年11月10日 （和暦明治 4 年 9 月 28 日）文部省に「運動場」設 置を伺い出た ${ }^{23)}$.

今般御改正二付而八厳正之規則相立成丈生徒 之外出ヨも禁じ健康に害無之様致し度就いて 八校中運動場取設候半而八不相叶存候尤も右 之義八先達而伺済相成候事故至急取掛り候様 致度此旨及御進達候也

辛未九二十八日

南校

\section{文部省}

伺之通

これが東京大学所蔵の「文部省及諸向往復文書」 で体育に関連してみられる最初の記録である。こ の文書から，運動場の設置はこれ以前に伺ってい たことが分かるが，ここでは生徒の健康のため学 校の中に運動場を設置したいとしていた．この伺 いが「伺之通」と認可されたのはそれから間もな い時期のことであり，しかも「学制」の頒布 （1872年 9 月 5 日）より 1 年前だったことに注目 しなければならない。つまり, 全国統一的な近代 学校制度が創設され,「体術」・「体操」が各学 校段階に導入される以前に早くも南校では運動場 を開設しょうとしていたのである。これは，新政 府の設立する学校で最も早くに体育の導入を図っ たものと言えよう。

しかし，この建設工事の着工が遅れたため, 南 校は 1872 年 2 月 $17 \cdot 20$ 日［明治 5 年 1 月 $9 \cdot 12$ 日）二度にわたって土木寮に着工方の督促をした が, 同 20 日土木寮から大蔵省と折衝中である旨 の回答があった。同日大蔵省からは, 四千八百九 十八両余を要する工事は財政困難の折暫く見合わ せたいと文部省・南校宛に回答がなされてい る ${ }^{24)}$ 。このため南校は同 23 日経費節減案を提出 して着工を要請した。こうした経緯があってのち 工事が行われたわけだが，同年 5 月 18 日には土 木寮に対して完工前の供用開始を通告してい た ${ }^{25)}$.

南校の学科課程（和暦明治 5 年 4 月）は, 外国 語別クラス編成がなされていて，その英1の部〜
9 の部, 仏 1 の部〜 6の部, 独 1 の部〜 4 の部の各 等級で月曜から土曜まで毎日 9 時から 9 時半迄の 30 分間「体操」が配されていた。この点もすで に明らかにされてきたところである。

ところで，1872 年 5 月 6 日（和暦明治 5 年 3 月 29 日）明治天皇が「南校」に行幸した際，内外 国教官の進講および授業の模様を天覧した後， 「御昼餐御少憩の後, 本校玄関より御馬車に召さ れ，運動場御順覧，生徒運動の様を 天覧あらせ られ，午後二時十五分文部卿以下奉送の裡に還御 あらせられたり」と『東京帝国大学五十年史』上 冊に記されている ${ }^{26)}$. しかし，ここに言われる 「生徒運動の様」を展覧された事実を示す記録は 「東京帝国大学五十年史料」および「文部省及諸 向往復文書」等には発見できなかった。ただ， 『太政類典』中の文書には次のような記録 ${ }^{27)}$ が残 されている.

\section{三月二十九日五年}

南校二行幸

第九字南校へ 行幸アラセラル文部省勅奏 任官御礼申上続テ御雇教頭フルベッキ拝謁 次二教場へ 出御フルベッキ随従ス教場 ニヨイテ内外教官等各其生徒ヨ引率シ来リ 講義手術等ノ課業

天覧二供ス畢テ御雇教師等へ 勅語左ノ通 フルベッキへ勅語

(略)

ガロー以下十九名ノ御雇教師へ 勅語

(略)

夫ヨリ昼ノ御食済セラレ 還幸ノ節馬車ニ

御シ、マ、運動場 天覧アラセラル言脽二十九日 この記述に従う限りでは還幸の際馬車の車上か ら運動場を展覧されたことは確認できるが，「生 徒運動の様」を天覧されたとは言えない。前述し たように，天皇行幸後の5月18日に至って完工 前の供用開始を通告したことを勘案するならば, 行幸時に「生徒運動の様」を天覧に供することは かなり難しかったのではないかと考えられる.

ともあれ，天皇行幸が予定され，また体操の授 業開始がせまっていたことがあって，前述したよ 
表 1 南校の時間表（一部）

（原文 縦書き）

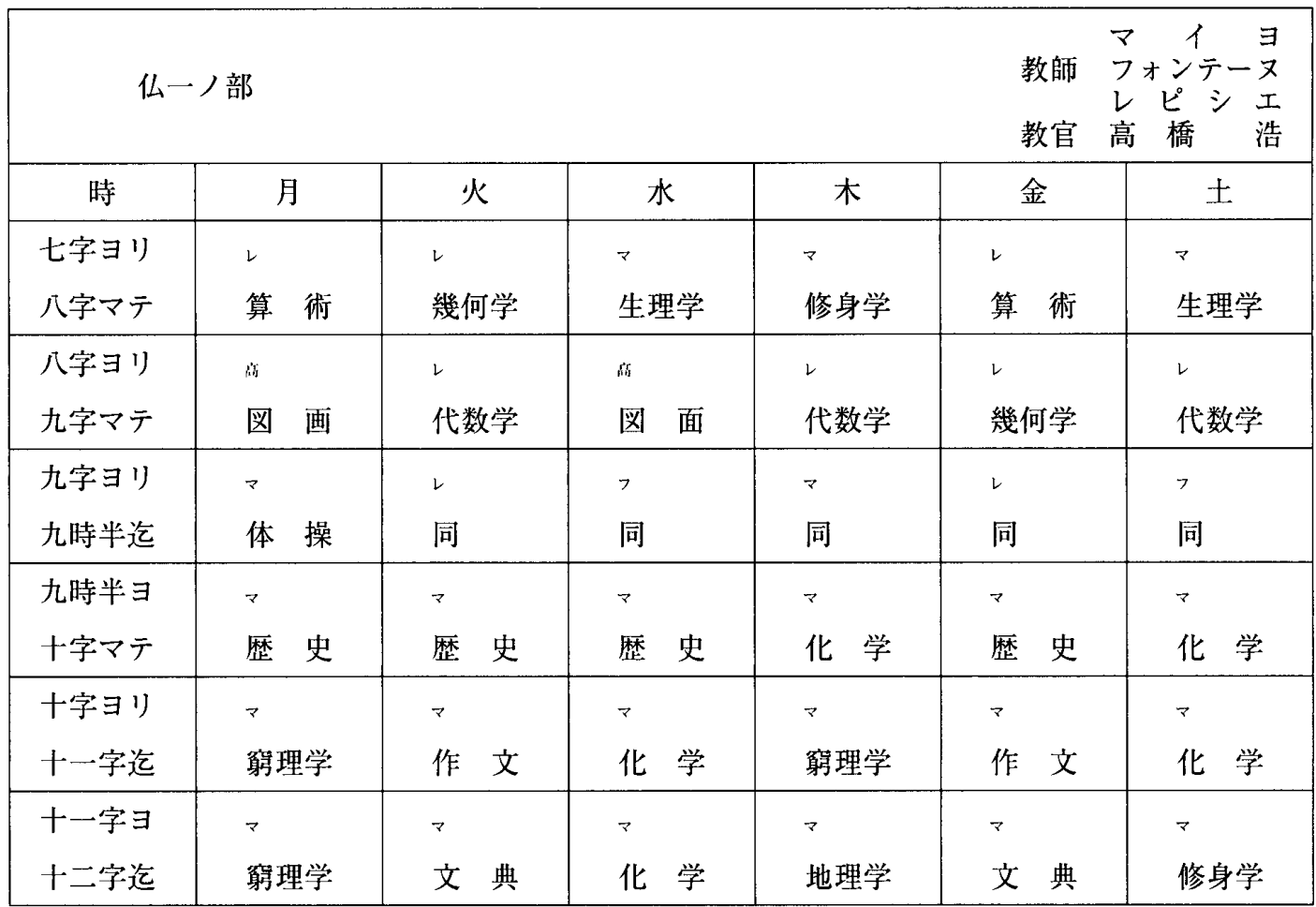

うに土木寮に運動場の建設を急がせたものと思わ れる.この運動場には体操器械が設置されていた と推測される，それは，後述するように，後に医 学校が南校の後身第一番中学に体操用器械設置に 関して視察を行い，絵図面を借用するといったこ とがあったからである，そうだとすれば，その体 操器械は, これも後述する体操授業の担当教師と の関係から見て，フランス式軍隊体操の体操器械 だった可能性が高い.

\section{2. 南校の体操教員}

南校の時間割（表 1）をみると，担当教師名 (外国人), 教官名（日本人）が明記されていて, 課目名の肩に片仮名一字の略称が付いているとこ ろが部分的にある.これは担当教師を表すものと みられるが，体操は英仏独各組各学年，毎日午前 9 時から 9 時半まで 30 分間時間割配当されていた が，この時間割で仏 1 の部〜仏 3 の部の箇所にだ けマ，レ，フと言うような略称がある ${ }^{28)}$.

担当教師に日本人教師 1 名とともにマイヨ, フォンテーヌ，レピシエの 3 名がいたので，これ らフランス人教師たちの名前の略記であると見ら
れる.この教師たちが体操を指導することになっ ていたか，あるいは実際に指導したことが考えら れるが，これを明らかにする史料は見いだされな い。これら 3 名の仏人教師についてユネスコ編 『資料 御雇外国人』は，次のように記述している (抜粋, 筆者 $)^{29}$.

マイヨ【原緅】Maillot【年齢】 3 年当侍 37 才【没年】 7 年 8 月 14 日（病死）【雇主臂期 間】大学南校・諸芸学校 $(3$ 年 8 月- 4 年 6 月烸日）開成学校（4年 7 月 1 日一 6 年 7 月 23 日満期 $/ 6$ 年 7 月 24 日一 8 年 7 月 23 日)【職種】 語学窮理学教師/仏語学窮理学教師/物理学化 学教師/諸芸学/物理学化学博物学/仏語学/仏 学教師/化学物理学教授/博物学教授兼務【備 考】授業時数 1 日 6 時間, 6 年 7 月 24 日より 1 日 4 時間

フォンテーヌ【原緅】Fontaine [Gonzalve] 【年齢】 5 年当時 28 才【雇主雇期間】大学南 校 (6年 9 月 1 日より諸芸学校), 東京開成学 校（5年 2 月 28 日- 8 年 4 月 3 日満期解約）

【職 種】仏学教師/文学教師/仏語学教師/諸 芸学/文学 
レピシエ【原緅】Lepissier【年齢】6年当時 46 才【雇主雇期間】大学南校 ( 7 年 1 月 1 日 上り開成学校) 東京開成学校, 第一大学区第 一番中学（5年 2 月 1 日一 7 年 6 月 11 日病気 により解約）【職種】数学教師/天文学教師 (7 年 1 月 1 日より)/諸芸学教師/天文学教師/ 天文学師（天文大学士）/仏学教師/仏語学教 師【備考】授業時数 1 日 6 時間内

この【職種】の項に体操を担当したという記述 はない.【備考】の一日授業時数を見たとき，マ イヨの場合の 6 時間から 4 時間への変更（レピシ エは， 7 年 6 月で解約されているので変更が見ら れない，またフォンテーヌには【備考】が欠如し ている）は体操担当がはずれたことも考えられる が不明である。

ともあれ，この時間割上の体操担当は，のちに 明らかにするようにフランス式軍隊体操の系統の 体操の採用・実施と関連してのことであったと推 測される.フランス人ならばフランス式の体操の 指導が出来るのではないかと期待されていたので はないだろうか．他のクラスには教師名が入って いないので指導教員が分からないが，この方は日 本人の体操担当教員を宛てることにしていたと考 えられる。「第一大学区開成学校沿革調」は, 明 治 5 年 4 月 8 日のこととして運動場開設と体操教 師採用による体操授業開始に関して次のように記 載 ${ }^{30)}$ している.

四月八日生徒運動所ᄏ置ク前比静岡県貫属福 島惟成荻谷祐之瀧野貞豊梶田寅太郎 於是体操教師トシ生徒习教授セシム

この記述によって，これら4名が南校の体操指 導を担当していたことが分かる.この点は, 先行 研究をとりあげたところで述べたようにすでに知 られているところである。これら 4 名の体操教員 のうち梶田寅太郎だけは経歴が不明だが, 福島, 苅谷, 瀧野の三名は幕府の軍隊でフランス式軍事 訓練の一環として体操を習得した旧幕臣であった と見られる。しかし，これら 4 名の詳しい履歴を 明らかにすることができない，ただし，福島惟成 （邦太郎）は, 維新後 1868（明治元）年静岡藩 (徳川宗家) の将校養成のために設立された沼津
兵学校付属小学校において「体操教授方」として, 苅谷祐之, 瀧野貞豊（耕一郎）の両名は「体操世 話方」としてフランス式軍隊体操の指導を行った 経歴は, 判明している ${ }^{31)}$.そして, 福島惟成だけ は「多聞櫓文書」に拠った『改訂新版 江戸幕臣 人名事典』に次の記載がある ${ }^{32}$.

福島邦太郎（ふくしま・くにたろう）

辰歳二十七 高三十俵三人扶持内十五俵御足 高一人半扶持御足扶持外御役金二十両本国 三河 生国武蔵 (中略) 祖父福島五左衛門死 黑鍬之者相勤申侯父福島為之助撒兵勤方相勤 罷在候 実子

元治元子年三月二十二日従部屋住被召出御留 守居同心被仰付 慶応元丑年五月八日御持 同心被仰付直二御進発御供被仰付 同二寅年 七月二十六日石州路為御用保科弾正忠殿附 属出張被仰付雲州松江表江滞陣仕御用相済同 年十一月九日帰府仕 同月十四日撒兵被仰付 同三卯歳三月十九日伝習御用被仰付 同年十 月廿六被肝煎被仰付 同四辰年二月七日歩兵 教導役被仰付 当辰年迄五ヶ年相勤罷在候

これは,福島の幕臣としての経歴を示すもので, 1864 （元治元）年出仕して，1865（慶応 2）年に は幕府の第二次長州征伐に従軍し, 州府後父同様 に撒兵となり，フランス式操練の訓練を受け，肝 煎になり，さらには歩兵教導役になったことが分 かる．体操の訓練もこの過程において経験したも のと見られる。

沼津兵学校の体操については当時同校の生徒だ った石橋絢彦が次のように述べている ${ }^{33)}$.

午後二時頃課業終れば銘々玄関に置きたる鉄砲 を荷ひ書物を包みたる風呂敷包みを携へ 練兵 場に集るなり此所には平岡氏以下数名の教官 銘々受持の生徒に教授す始めは市馬手摺などよ う竹飛び棚飛など種々あり…棚飛芸の内，棚の 上に仰向に臥し首を棚の外に出し足より上げて 体を棚下に落すは馴るれば容易なるも神経質の 人は好ま妓なりし 此外に首振りを始め手足 の運動，駆定等種々あり（強調点筆者）

このように, 沼津兵学校では木馬・平行棒・棚 などの器械体操・竹飛（棒高跳び）・徒手体操 · 
走運動などを行なっていたことが分かる．新政府 による近代学校体育創設の初期には幕末に洋式の 体操を学んだ旧幕臣がまずはその指導者の役割を 担うことになったのである。

なぜ南校でフランス式軍隊体操が採用されたの かと言えば，南校は天文方に発し，蛮書和解御 用・洋学所 - 蕃所調所と幕府の西洋文化研究セン ターの役割を果たしてきた機関の系譜に属してい たこと，また幕府は幕末に軍隊にフランス軍事顧 問団による本格的な洋式訓練を受けさせて，軍隊 体操の経験をもつた軍人を生み出して, 維新後も 実際に沼津兵学校・同附属小学校でその指導を行 のを南校当局者が知っていたことなどによって， 南校はその体育の指導者として沼津兵学校附属小 学校の体操教師を雇用した結果であったと考えら れる。

なお，明治 5 年の南校「舎則」には，次ぎよう な規定があった ${ }^{34)}$.

一 朝第六字ヨリ夜第十字迄 7 家業時間卜ス 内午前三字間午後二字間 7 正課時間卜ス正課 後ノ二字間八体操及ヒ外出散歩ノ時間タルベ キ事

但夏月八朝第七字ヨリ昼第十二字マデ正課時 間タルベキ事

このように，南校では正課の体育の他に課外の 体育も奨励しょうとしていたことが分かる。こう して，南校では体育を重視していたということが できよう。

\section{III 第一大学区第一番中学の「体操」}

1872 年 9 月 5 日（和暦 5 年 8 月 3 日）「学制」頒 布にともなって，「南校」は「第一大学区第一番 中学」(以下「第一番中学」と略称する) と名称 が改められ, 専門予備教育を施す学校とされた。 ここでも南校と同様に「体操」が学科目に位置づ けられていた ${ }^{35}$. 1872 年 10 月 29 日（和暦明治 5 年 9 月 27 日）付で福島惟成, 获谷祐之, 瀧野貞 豊, 梶田寅太郎の 4 名の体操教師雇い入れを文部 省に伺い出た文書 ${ }^{36)}$ によって，「南校」の体操教 員がそのまま「第一番中学」の体操教員となって
いたことが分かる.

第一番中学のときは上記 4 名以外に竹村頼堅, 在田為憲, 長尾吉之助, 鈴木有季の 4 名の名前が 挙げられており，併せて 8 名の「体操教師」がい たことになる ${ }^{371}$. 竹村ら 4 名の経歴も不明である が, 福島等 4 名と異なって雇い入れ関係の文書が 残されていないところからみると雇用関係が別種 の扱いであったのではないか. 竹村らは, 沼津兵 学校付属小学校における「体操教授方」に対する 「体操世話方」の関係と同じように, 福島等 4 名 の教員の補助的な役割を与えられていた可能性が 考えられる。

ともあれ，福島等 4 名の体操教員が引き続き指 導したのは，南校と同様に器械体操を主としたフ ランス式の軍隊体操であったと考えられる。

なお，第一番中学のとき，「東校」は「第一大 学区医学校」と改められていたが, その医学校か ら体操器械設置に関して照会と実地見学が申し込 まれ，これに協力して体操器械の絵図面まで貸し 出している。この点は後述することにするが, 「体操」実施に関しては南校一第一番中学の方が 東校一第一大学区医学校より先行していたことが 明らかである．第一番中学の時期は, 約 8 个月余 の短い期間で，開成学校となる。

\section{IV 開成学校と「体操」}

\section{1. 体操場 (戸外) の整備}

第一大学区第一番中学は，1873（明治6）年 4 月 10 日専門学の教授を目的とした「開成学校」 と改められ，校舎も新築された（1873 年 8 月）. 学校所在地が神田一橋町一番地から神田錦町三丁 目一番地に移った。開成学校から 7 月 27 日付で 戸外の「体操場」地二千六百五十六坪五合を整地 する伺書 ${ }^{38)}$ が出されている.この体操場は, 北 側が南側より 13 間長い台形になっていた（四1）。 この体操場の整備は，実は 1873 年 2 月 12 日「第 一番中学」が寄宿舎を「高燥」の地である運動場 に新築したいとして本省に伺い，同 14 日に認可 されていたので ${ }^{39)}$ ，このため一時「仮体操場」を 設けていたが，開成学校の校舎新築にともない新 


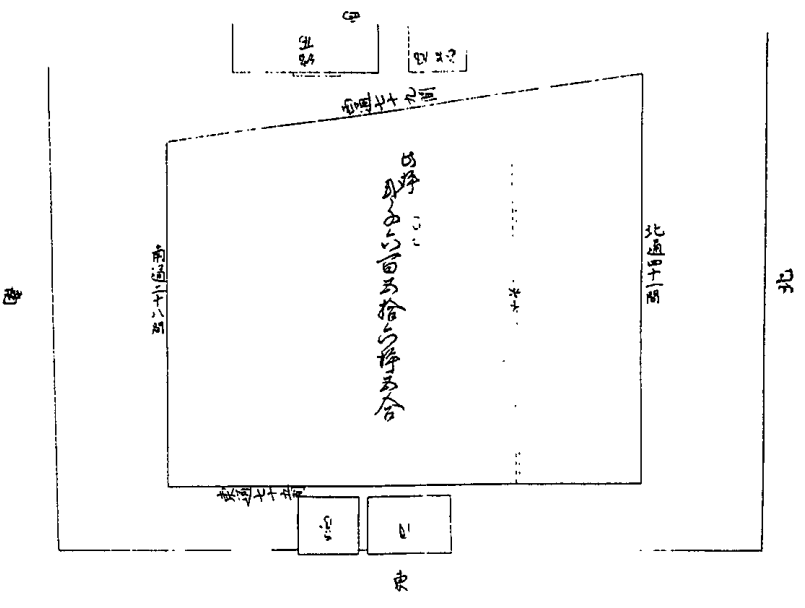

図1開成学校体操場平面図（東京大学史史料室）

に体操場を整備する結果になったものと見られ る.

\section{2. 副科としての「体操」}

「体操」は, 開成学校の学科目中に掲げられて いなかった ${ }^{40)}$.しかし, 実際には諸芸学の課程は 別にして, 法学, 理学, 鉱山学の各課程で, 予科, 本科とも時間割表に月曜から土曜日まで，毎日午 前 9 時半から 10 時まで「体操」が配されていた ${ }^{41}$. つまり,「体操」は正科（課）ではなくて, 副科 の扱いだったのである.「第一大学区東京開成学 校規則 ${ }^{42)} 」 の$ 第五章学課定則には,

第三条 体操八休㴧時間ニ行フト雖卜モ尋常 遊戯卜視倣スヘカラス生徒健康 ノ在校勤学 全シ人々卒業ニ至ラシムルノ功 用二於テ益スル者トス

とあり，体操は，休噁時間，すなわち業間に実 施されるものであった。それでも，これは保健の 価值を有するもので, 普通の遊戯と同一視すべき ではないと重視していたのである。

「東京開成学校第二年報」（明治七年）に「体操 規則 厳ニシ生徒 7 分チテ四隊卜ス爾後疾病路事 故アルニアラサレハ久課スルヨ許サス」 ${ }^{43)}$ とある のは，このことを指していると見られる．副科で はあったが，ほとんど正科に近い扱いだったと言 えよう。

また，同規則第一章には，次の規定があった.

第十四条 此学校八旁二洋風ナルノミナラス
授業交它体操等う便利广ル力為文可成洋服 ヨ着スヘシ（強調点筆者）

この洋服着用の規定に関連するものとして， $1874 （$ 明治 $7 ）$ 年 5 月 2 日開成学校長畠山義成か ら木戸文部卿に宛てた次の伺書 ${ }^{44)}$ が出されてい た。

当校之義者外国教授 処外来生徒ノ如キハ其衣服整一ナラス 大凡外套 ヨ穿チ袴ヨ着ケ候モノニテ右者器械ノ使用体操う 運動等三於宁天文不便斗生シ 候間先年生徒一般 沓 穿ツベキノ令 $ヨ$ 出シ候事も有之義二付右之例 Э以テ外来生徒一般 洋服着用為致申度候条此段 迅速御指令相伺候也（強調点筆者）

日本の学生・生徒の洋服着用は, 一般に兵式体 操の導入にともなって普及したと見られるが，こ の兵式体操の導入以前に, 開成学校 - 東京開成学 校では器械使用・体操運動の便を図って洋服着 用・靴使用の普及が進められていたのである。

さらに，1875年の「校則」中の「生徒心得 ${ }^{45} 」$ にも次の規定が置かれた。

第六条 体操八健康 要ナルョ以テ規則二循ヒ必ズ之ヨ勉ムベシ 又休息時間八散歩競力戯芸等運動ノ為入必ズ 之ヨ為スベシ

ここでは体操を重視しているが，またスポーツ 等を指していると思われる「競力戯芸」を散歩と ともに運動として行うべきものとしていた，翌 1876 年改正「校則」の「生徒心得」は，「競力戯 芸」を「戯芸」と改めていたが，体操を重視して， 次のように体操教員の配置を明記していた ${ }^{46)}$

第一条 生徒夕ル者必不散歩, 戯芸, 体操等 ヨ為シ以テ身体ノ運動 ヨ附シ其術 演習セシム（強調点一筆者）

こうして, 体操を副科と位置づけていた開成学 校・東京開成学校ではあったが, 実際には生徒に 洋服着用・靴使用をさせ，身体運動を奖励し，と くに体操を重視し，その指導のために体操教員を 配置することとしていたのである. 


\section{3. 体操場の工事と体操器械の設置}

上述した体操場の整地伺い ${ }^{47)}$ と同日（1873年 7 月 27 日）付で体操場内の土手の建設（25円）お よび体操器械の設置 (135円) の伺書 ${ }^{48)}$ が出され ている，後者の体操器械設置の伺書は，山浦孝太 郎が 165 円で工事を落札したので請け負わせたい とするもので,これには設計書が添付されていた。 この設計書が先の第一番中学の体操器械「絵図面」 と同じものであったのか否かが問題だが，同じも のであったなら新設でなく移設で間に合ったと考 えられるので，違った図面と見られるのではない だろうか.ともあれ，この設計書には跳縄，木馬， 手摺, 矢倉, 鈞縄, 釣木, 木梯等の体操器械が挙
げられていた（図 2-1，2-2参照. 図 2-2は，史 料では6枚のものを筆者が合成したものである). これらは, 田辺良輔訳『新兵體術教練』(明治元 年刊）に掲げられた器械体操の体操器械 ${ }^{49}$ と類 似したものである（図 3）。ここで手摺というの は後に平行棒として定着するものであり，矢拿は 設計書と照らし合わせた場合沼津兵学校で棚と称 されていたものと見られる。

『新兵體術教練』は，幕末シャノワンらフラン ス軍事顧問団が幕府陸軍に教授した体操であった とみられている ${ }^{50)}$. 従来『新兵體術教練』の)体操 が学校で実施されたか否かは不明であった。それ が，この設計書によって実際に開成学校で京様の
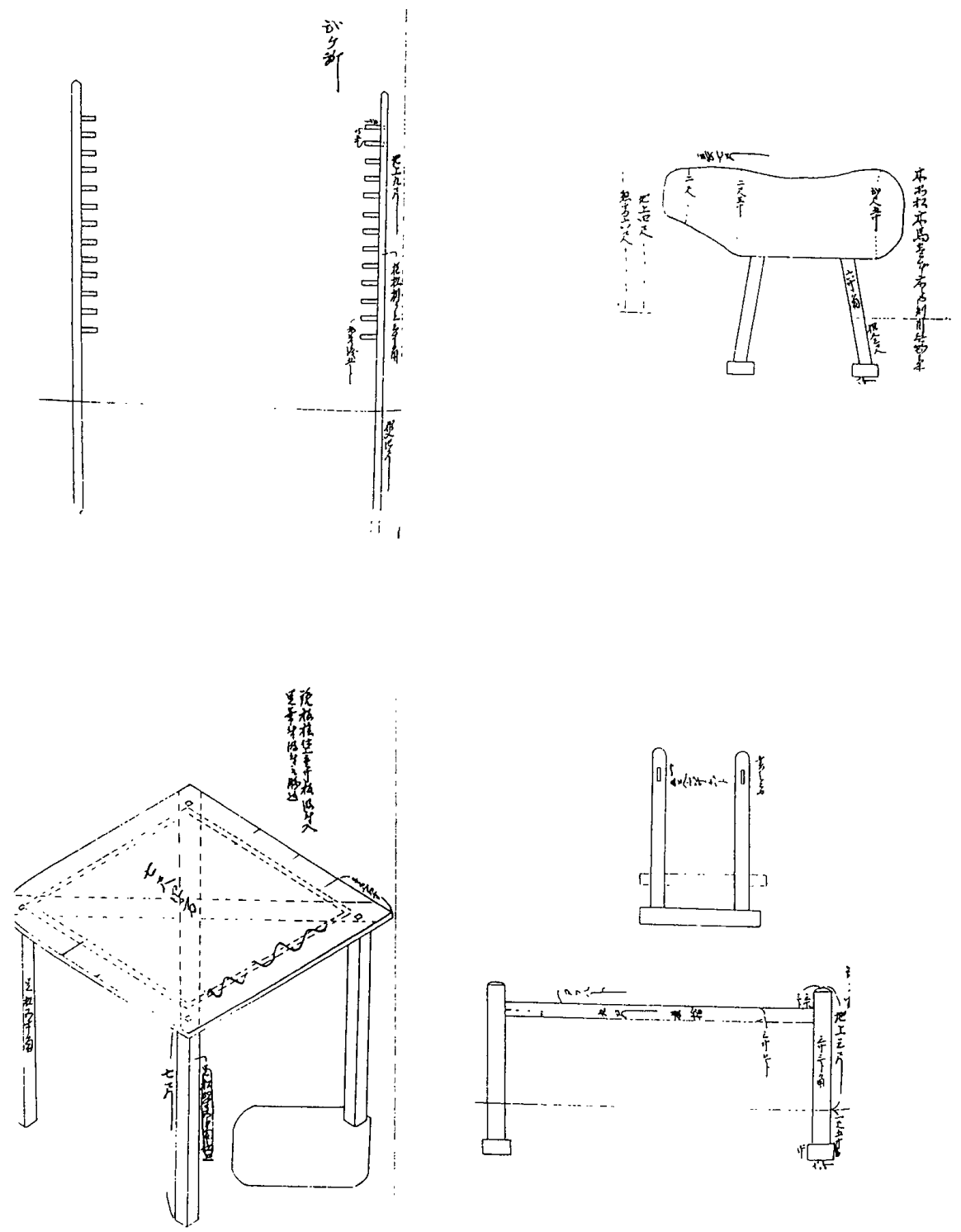

図2-1 開成学校体操器械設計書 1（同前） 

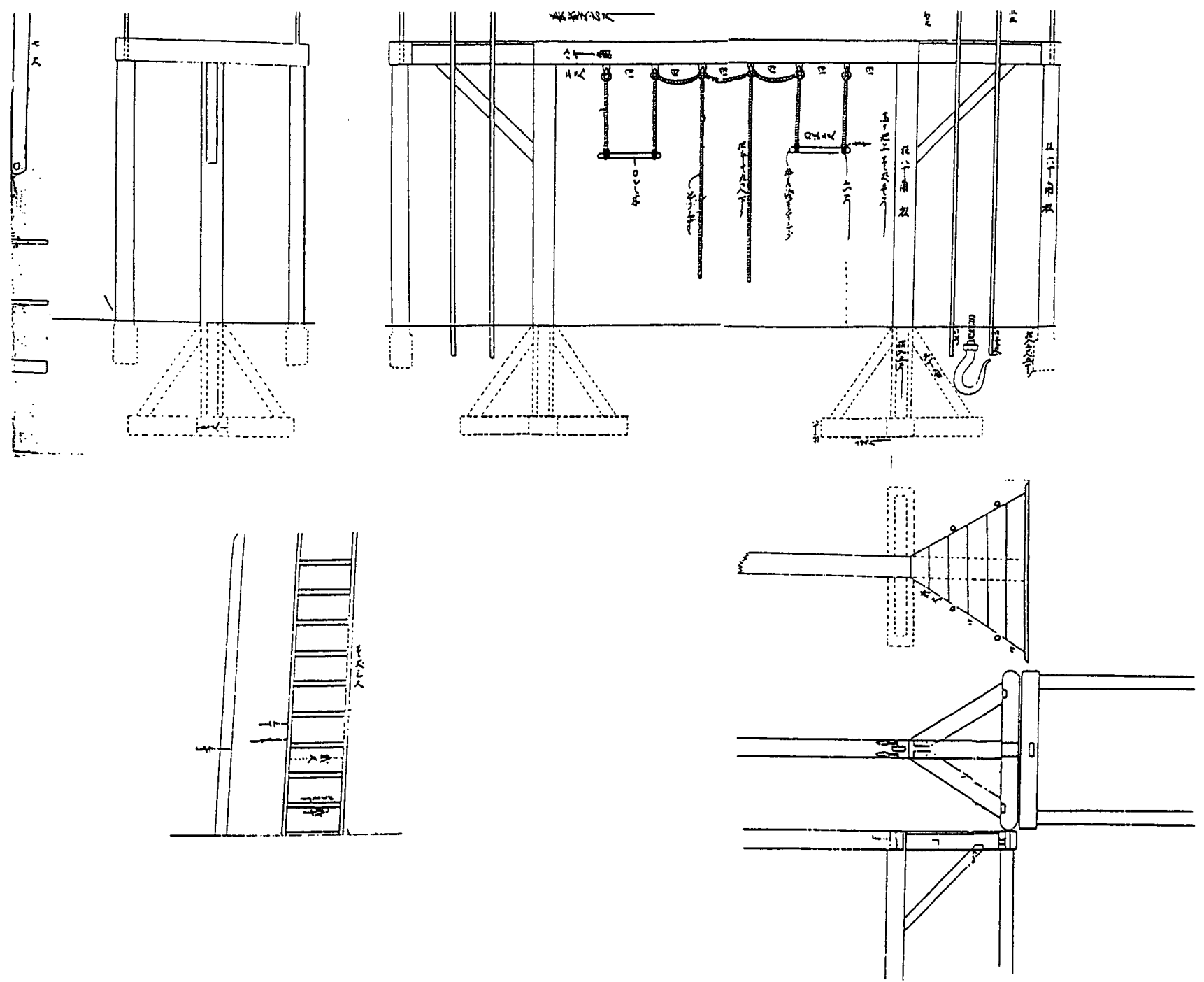

図2-2 同 2（同前）

体操が実施されたことが明らかになる．ただし， この場合『新兵體術教練』を「主に伝習経験と実 見，簡単な号令詞を基にして著わされたものであ り，おそらく原書とは違っているいるであろうと いうものであった」とし，これに対して林正十郎 『木馬之書』は「シャノワンらが持ち込んだフラ ンス体育法が, 単に伝習経験と実見, 簡単な号令 詞に基づく原書的な研究であっただけでなく， Instruction pour l'enseignement de la gymnastique という原書に基づいた，しかも仏語に堪能 な開成所教授職の手になる, 洋学研究の一つとし て学問的に評価されるべき研究であった‥」とい

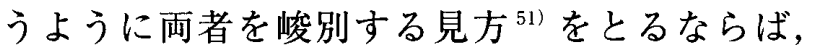
開成学校の設計書の体操器械と『新兵體術教練』 の体操器械とでは，表 2 に明らかなようにほとん
ど共通であったが，前者には跳台がなく，代わっ て梁木に攀登棒と階梯が付属していて, 体操器械 が複雑化した構造となっていたことが分かる。た だしここの体操器械で［］で示したものは設 計書および『新兵體術教練』書中に名称が見いだ されないものであり，（）で示したものは『新 兵體術教練』書中の器械または運動の名称である.

このようにより複雑化した器械を見ると，この 設計書を作成した人物あるいは作成に協力した人 物は，『新兵體術教練』以上の知識を持っていた 者で，上記のInstructionのような原書によって その知識を取り入れることのできた者であったと 推測される。いずれにしても，ここでは幕府陸軍 の採用したフランス式軍隊体操の系統の体操が開 成学校で実施されたことが明らかである。これを 

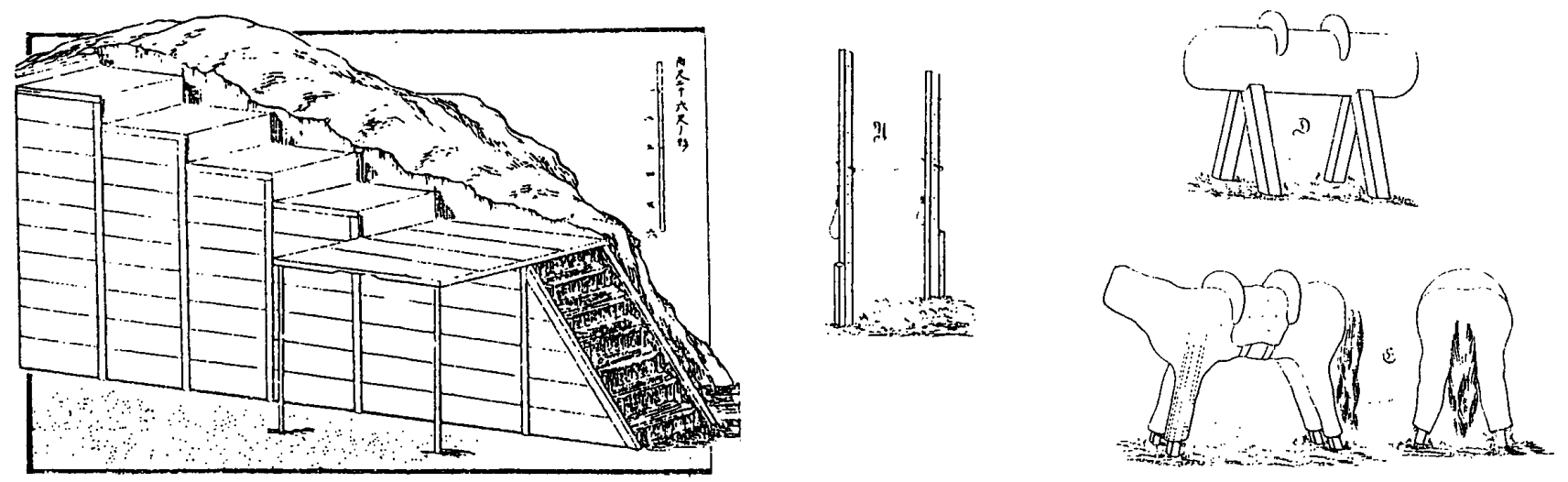

図 4-1 ヤーン・アイゼレンの体操器械の一部]

(Die Deutsche Turnkunnsut, 1816)
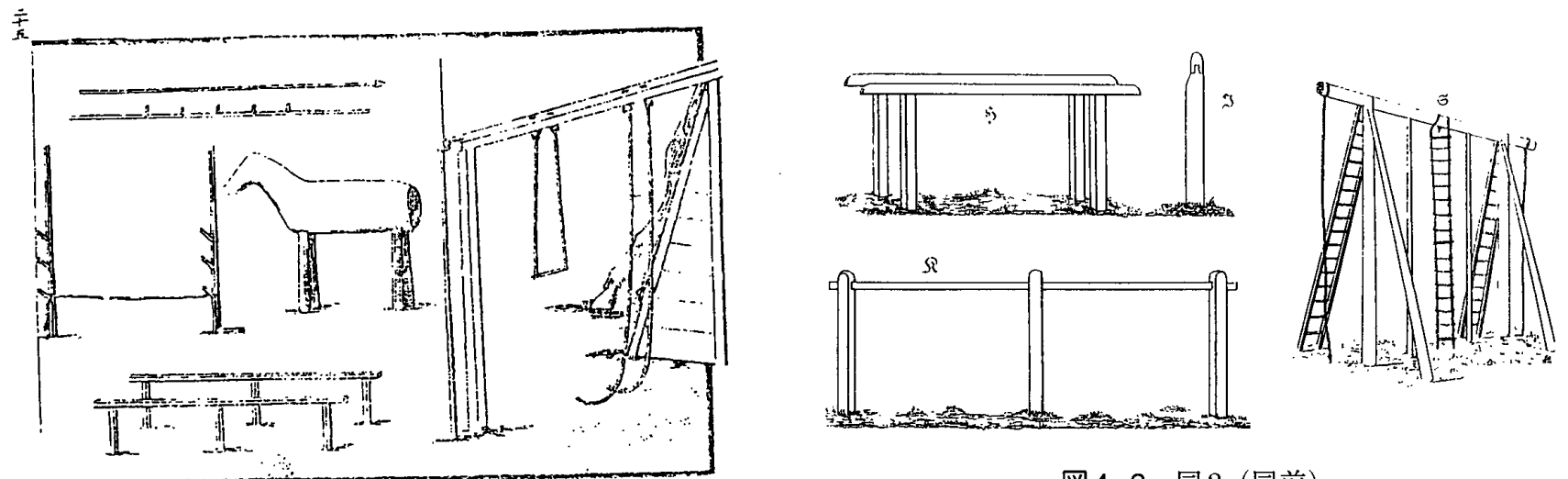

図3『新兵體術教練』の体操器械

表 2 開成学校と『新兵體術教練』の体操器械の比較

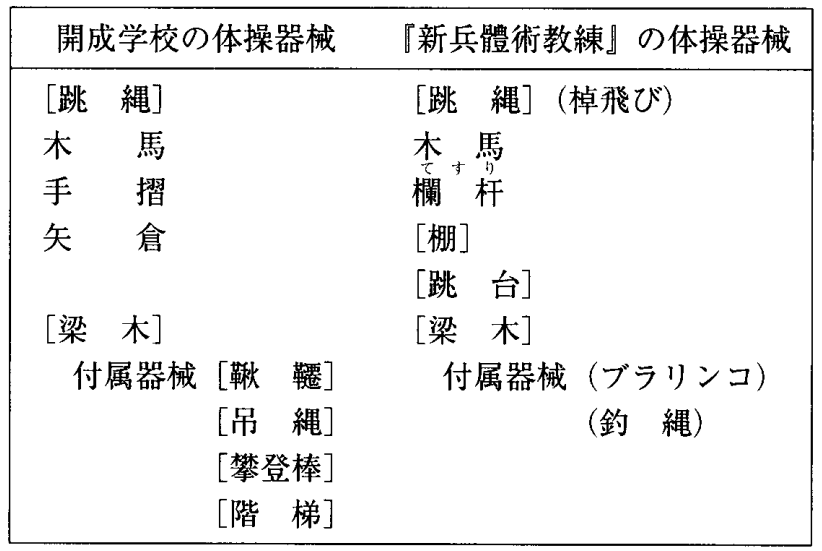

指導する体操教師に関して言えば，前述したよう に沼津兵学校ですでに同種の体操を指導してきた 者であった．また，このフランス式軍隊体操の源 流を尋ねるならば52)，それはアモロス（F。 Amoros，1770-1848）の体操に至り，そこから さらにドイツのヤーン（F.L. Jahn, 1778-1852)
らのトゥルネン（Turnen）にまでさかのばるこ とができるのである（図 4-1，4-2）。

\section{4. 開成学校開業式における体操の天覧}

1873（明治6）年 10月 9日明治天皇が「開成学 校開業式」に臨幸された際，諸科生徒によって 15 分間天覧に供された体操が(1)行飛(2)手摺(3)矢 倉であった ${ }^{53)}$ 。これらの種目によって，やはり上 述したフランス式軍隊体操が害際に開成学校で実 施されていたことが確認できる。ここで行飛とい うのは, 沼津兵学校付属小学校の運動に照らし合 わせると竹飛と称されていた棒高跳びではないか と考えられる。このときの体操指導教員は，以下 に示す人名表から蒱谷, 滝野, 福島であったこと が分かる ${ }^{54)}$. 
天覧體操技術教師並生徒人名

生徒

臼井 済
西川鉄二郎
松岡 政人
三村德太郎

右行飛 演フ

教師
莍谷 祐之
生徒
福田 良作
小澤 徳平
橋詰源太郎
和田維四郎

右手摺ヨ演フ

\section{教師}

滝野 貞豊 生徒

小木 貞正 宮原 直克

冨塚恂

瓜生泰

關澄蔵

右矢倉 演フ

教師

福島 惟成

こうして，幕末に輸入されたフランス式軍隊体 操の系統のものが, 沼津兵学校を経由して, 新政 府の西洋式の教育を行う開成学校で実施され，天 覧に供されたのである.

\section{5. 体操教員の雇止}

1874（明治 7）年 5 月 7 日開成学校は「東京開 成学校」と改称されるが，同校の1876（明治9） 年 11 月の「人員調査表」55) まで, 毎回の人員調査 表に苅谷祐之（忠三)，滝野貞豊の両名の名が継 続して記載されていた。しかし，同年11月 30 日 には加藤市次郎，津金胤全の両名が臨時に雇用さ れている ${ }^{56)}$ 。これは，前月 24 日苅谷祐之が依願 解雇となったことによるものと推測される。こう した体操教員の存在と後述するようなその異動か
ら判断して, 東京開成学校では開成学校と同様に 1877年1月末まで引き続き副科ではあるが正科に 近いかたちでの「体操」が実施されていたと見ら れる。しかし，その体操実施の具体的状況を示す 史料は，管見することができなかった．

1874 年 12 月 27 日東京外国語学校の英語科を分 離して「東京英語学校」が設立された。これは, 専門学科を学ぶための予備教育を施す教育機関と して設けられたもので下等語学科・上等語学科各 3 年の課程があったが，いずれも教則中に「体操」 が置かれていた ${ }^{57)}$. 東京開成学校の体操教員苅谷 祐之, 滝野貞豊の両名は, この東京英語学校の体 操教員を兼務していたことが雇い入れ関係書類か ら明らかになる ${ }^{58)}$ 。

しかし，1877（明治 10）年 1月 19 日加藤市次 郎・津金胤全 ${ }^{599} ， 2$ 月 2 日滝野貞豊がそれぞれ雇 止となる ${ }^{60)}$. 同年 4 月 12 日東京開成学校と東京医 学校が合併して東京大学となったが, これらの体 操教員の雇止は, 東京大学予備門生徒は体操伝習 所によって「体操」の指導を受ける新しい体制に 移行することになったのにともなう措置であった と見られる。この移行は，東京大学前史における 体育の終結を意味する極めて大きな変革であっ た.

\section{6. 体操図・筋骨運動器械・ゴム鞠}

開成学校・東京開成学校の時代, 前述した体操 の指導や教員に関する文書以外に，体操図，筋骨 運動器械，ゴム鞠などに関する文書が残されてい る. 体操図（正確には「榭中体操法図」だが，文 書では「体操図」とのみ記載されている）が翻 訳・出版されたのは周知のように南校時代の 1872 年 8 月（和暦明治 5 年 6 月）であったが，こ の翻訳・出版の経緯を明らかにするような文書は 見出されない.

まず，体操法図に関しては，太政官第廿五号達 によって官版書籍は書籍館に送付することになっ たので, 開成学校蔵版の書籍（図法階梯・体操法 図）各一部を文部省准刻課へ送付するようにと求 められ，これを差し出す旨回答した文書 ${ }^{61)}$ (明治 7 年 3 月）がある。同様に両書を文部省に差し出 


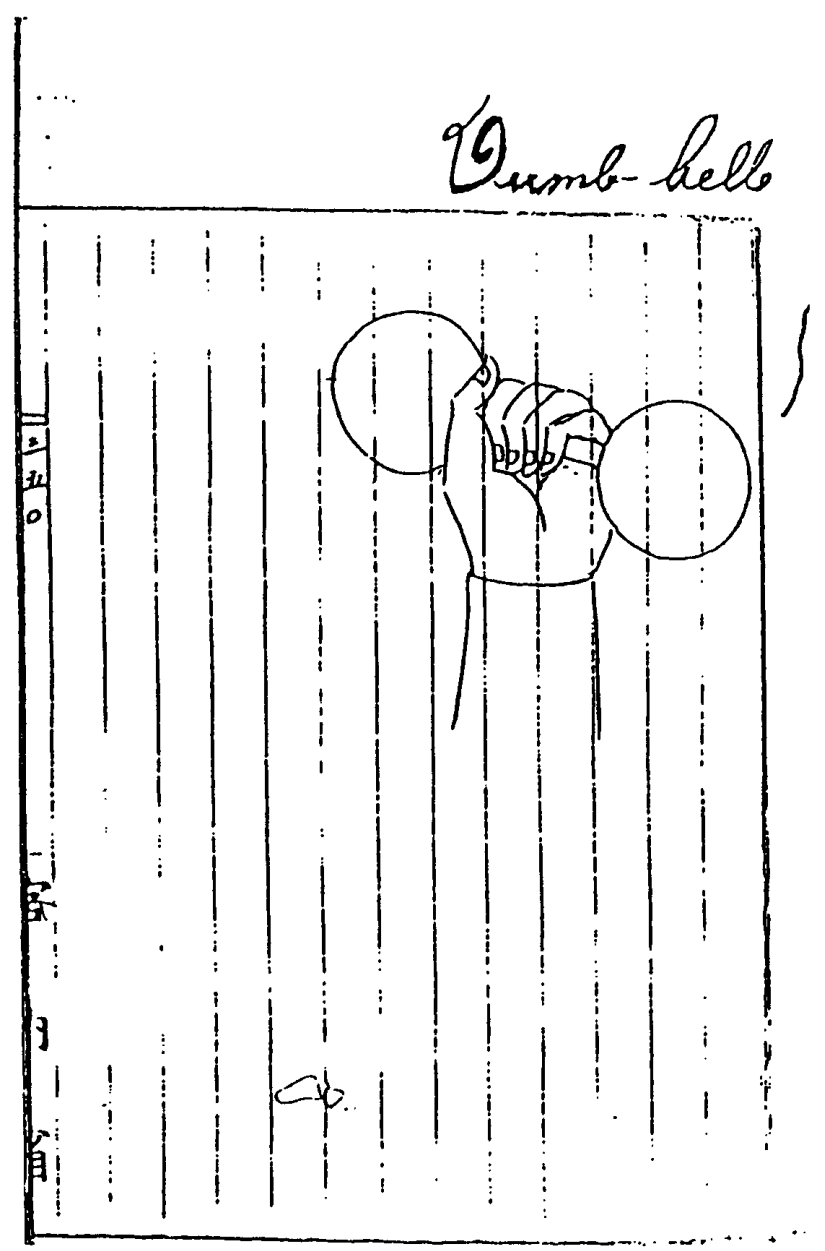

図5 筋骨運動器機（東京大学史史料室）

せとの文書 ${ }^{62)}$ (同年 8 月)，さらには同年 10 月大 阪師範学校から両書を譲り受けたいとの依頼があ ったが，東京開成学校はすでに版木を文部省に納 めてしまったので，文部省の方から送付されたい との回答を行った文書 ${ }^{63)}$ などがみられる.

次に，筋骨運動器械を製造していたことを示す 文書がある，宮内省から別紙図面（図5）のよう な東京開成学校製造の「筋骨運動器械」大中小三 種が入用なので送付されたいとの依頼（明治 9 年 4月 21 日付）を受けた文部省学務課長からの照会 （同年 4 月 27 日）があり，これに5月18日送付し たとの回答 ${ }^{64)}$ を行っている，図面から，そして Dumbbell と英語の名称も添えられていることか ら明らかなように，筋骨運動器械というのは亜鈴 であった。宮内省に納めたときの文書の別紙 ${ }^{65)}$ には次のような記載があった。

図略
大ナル者 一対ニシテ其量

三貫三百目

片鉛ノ量 二百五十目

百目

百目

中ナル者

同

二貫目

片鉛＼cjkstart百目

八十目

四十目

小ナル者 同

壱貫目

片鉛＼cjkstart六十目

四十目

二十五目

管骨運動器ハ如図雨球各螺旋 着シ球内ニ片鉛ヲ蔵スルニ因リ若シ之ヨ軽重 セント欲スルトキハ其片鉛 7 適宜ニ附脱スル 事自在ナルベシ

このように球とその中に入れる鉛は着脱式で重 量を変えられるようになっていた。東京開成篎校 では代価を宮内省に未だ請求していないので能納 としたい旨を学務課長に伺い（同年 12 月 21 日） 了承（同月 27 日）された。このとき学校側ぐは 代価を大・拾三円，中・十円，小・八円と見積も っていた。こうして，体操伝習所における「埾体 操」の選定以前に東京開成学校では亜鈴を製造し ていたこと，そして伝習所の木製の亜鈴とは猉な り，大・中・小三種類のものがあり，しかも球内 に内蔵する鉛は着脱式で重量を変える複雑なむの であった。ただし，これが東京開成学校の実際の 「体操」授業で使用されたか否かは不明である。

さらに，ゴム鞠の修理が行われていた。明治 10 年 1 月 9 日東京外国語学校から破損したゴム鞠 6個の修理依頼 ${ }^{66}$ があった。このゴム鞠がスボー ツで使用されたものか不明だが，その可能性は考 えられる. 東京開成学校では最初修理を断ったい る.しかし，外国語学校から吏員が直接出向いて 重ねて依頼したので修理に応ずることにしてい る.

以上のように，近代産業の未発達な明治初期に あっては, 天文方・蛮書和解御用・洋学所・萫所 
調所という幕府の西洋文化研究センターの系譜を 引く南校・開成学校・東京開成学校は, 体育専門 書の翻訳出版・スポーツ用品製造の役割まで担わ ざるを得なかったのである.

\section{V 第一大学区医学校の「体操」}

以上，大学南校から東京開成学校に至るまでの 体育について考察してきた.ところで, 大学東校, 東校, 第一大学区医学校, 東京医学校と変遷し, のちに東京大学医学部となって東京大学に統合さ れる系統の学校の体育についても取り上げなけれ ばならない。しかし，『東京帝国大学五十年史』 上冊が「医学校, 東京医学校の規則及教則に関す る記録類の徴すべきべきもの多からざるを以て， 今日に於て明瞭にし難き点な少なからず 67$\rfloor$ とあ るように，その体育に関してもこれを十分明らか にすることは困難である。しかし，その限られた 史料から浮かび上がってくるこの系統の学校の体 育は，以下にみるように第一番中学・開成学校の 協力のもとに，これに倣うかたちで実施されてき たのである。

\section{1. 第一大学区医学校の体操実施}

南校では前述したように「学制」施行以前の 1871 年 11 月[和暦明治 4 年 7 月]「運動場」開設の 伺いをし，1872 年 5 月[明治 5 年 4 月]には福島惟 成・滝野貞豊ら 4 名の体操教員を雇い, 体操の指 導に当たらせていた。「学制」の施行にともなっ て南校が第一大学区第一番中学と改められたと き, 東校は「第一大学区医学校」と改称された。 第一大学区医学校は，司馬盈之・三崎啸の両人に 貸渡地所の明け渡し請求（1873年 1 月 7 日） ${ }^{68)}$ 行って，「体操所」を設置することにした。この ため入札を行ったので至急「体操場」の工事をし たいと本省へ願い出ている ${ }^{69)}$. しかし，第一大学 区医学校の学科課程に「体操」は置かれていなか ったし, その後の医学校, 東京医学校でも学科課 程には入らなかった ${ }^{70)}$. したがって，南校や第一 大学区第一番中学では学科目中に位置づけられて いたのに対して，この東校から東京医学校に至る
系統の学校では一貫して正科外に行う考えであっ たと見られる。そこでは，南校の系統の学校より も専門教育の色彩を濃くしていたことと関係があ ったのではないかと考えられる.

\section{2. 第一大学区医学校の体操用器械設置}

1873 年 3 月 22 日第一大学区医学校は, 先にも ふれたように,体操場に体操器械を設置するため, 第一番中学宛に体操用器械設置に関し職員を派遣 するので実見させ，器械の寸法なども教えてもら いたいとの依頼 ${ }^{71}$ を行った。このことから，体 操に関しては南校・第一番中学の方が先行してい たことが分かる．第一番中学は, 医学校の派遺職 員に対して体操教師が立ち会いの上委細説明する こと，そして暫時「絵図面」を貸出すので用済み 次第速やかに返却されたいと回答していた ${ }^{72}$.こ の「絵図面」は, 開成学校の体操場新設の伺が 1873年 7 月 27 日であったことから考えるならば, 先の南校の運動場設置のときに使用した「絵図面」 だったのではないかと思われる，しかし，この絵 図面は残されていない。

\section{3. 体操教員の兼担}

医学校は第一番中学の体操器械を参考にしただ けでなく，さらに開成学校の体操教員に医学校の 「体操」を兼担させていた．1873年 12 月 15 日医 学校は, 「当校生徒体操之義者其之教員無之二付 キ全ク其一科 $尹$ 欠キ候得者飲食ノ消化不定ヨリ 往々疾病二䍜り候者不少将来成業之目途有之候者 モ不得止廃学二及侯次第実二慨嘆之至リ不

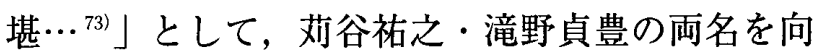
六ヶ月間雇い入れたいと本省に開申した。この結 果, 開成学校に対する次の申し入れとなった ${ }^{74)}$.

\section{荻谷 祐之 \\ 滝野 貞豊}

右者御校御雇教員二候處当校二於テも雇入申 度尤も貴校授業之時間二者決シテ不障様可 致候間此段御承知相成度御頼談旁及御掛合候 也

明治六年十二月廿日

第一大学区医学校長心得 
長谷川 泰

第一大学区開成学校

伴 正順 殿

これに対して，開成学校は差し支えない旨回答 したので 75)，12月 16 日付けで雇用されている。 こうして体操器械と体操教員の点から見て, 医学 校も南校 - 第一番中学 - 開成学校と同様の「体 操」，すなわちフランス式軍隊体操を行っていた ことが明らかである。

\section{4. 体操時間と体操告諭}

第一大学区医学校の「体操」は, 先にも述べた ように開成学校に見られたと同じく学科目に掲げ られた正科ではなかった。しかし，実際には 1873 年 12 月 16 日から本科 - 予科とも午後 2 時か ら 3 時の間各 30 分宛実施されていた ${ }^{76)}$. 開成学校 と同様に副科の扱いだったと見られる。実施開始 の翌日，17日に医学校は, 学生に向かって次の ように体操の趣旨 ${ }^{77)}$ を強く説いていたことによ って，副科ではあっても重視されていたことが分 かる。

身体ハ精神ノ舎ル所ナリ身体健康ナラサレハ 精神亦活発ナラス之ヨ譬フルニ身体八猶家 屋ノ如ク精神ハ猶人ノ如シ蓋家屋頽敗風雨漏 滲スレハ人必疾病二䍜リ身体患フ所アレ 八精神亦恙ナキ事ヨ得ス故二就学ノ士体操 演シ身体 シ蓋シ身体ヨ運動スルトキハ即千新陳代謝ノ 機旺盛スルトキハ即千飲食消化ノ機旺盛ス 飲食消化ノ機旺盛スルトキハ即チ百体栄養ノ 機旺盛ス百体栄養ノ機旺盛スルトキハ即チ 精神活発浩大トナリ能ク広汎ノ学科二耐エル 事 得可ク能ク精徵（緻の誤り一筆者）ノ事 理 7 了解記臆シ得可シ是体操 $ー$ 一学科トナス 所以ナリ満校ノ諸士能ク是旨趣 $尹$ 体認シ克己 勉励毎日定刻場二赴キ其身体 強健二シ其精 神 活発ニシ能ク広沉至難ノ学科二耐エ前途 ノ成業 二副ン事 若シ此規則二悖戻シ惰䛱体操セサ ルモノアルトキハ必至当ノ罰二処スルモノ ナリ
このように身体の健康が精神の活発な活動を支 えるものとし，その身体の健康は身体の運動によ ってもたらされるものであり，それ故に体操を行 う必要があると説いていた。体操は，「医道」を 興起するという大きな目的のために必要な学科と 位置づけられていたのである。

\section{VI 結 語}

以上, 東京大学が大学南校・大学東校の時期か ら東京大学に統合されるまでの期間の歴史を東京 大学前史とし，「東京帝国大学五十年史料」拉よ び「文部省及諸向往復文書」等の史料に基づいて， そこでの体育の導入と実施の状況について考察 し，体操伝習所によって日本の近代体育の本格的 な創出が始まる以前の体育実施の状況を明らかに しようとしてきた。ただし，純然たる課外のスポ ーツ活動は，考察の外に置いた，考察の結果明ら かになったのは，以下の点である。

1）南校は，「学制」頒布以前，1871 年 9 月文部 省に運動場の設置を申請し，翌年工事を行い，5 月 6 日天皇が行幸した際, 運動場を天覧に供した。 この運動場にはフランス式軍隊体操の体操器械が 設置されていたと推測される，新政府設立の近代 学校として最も早くに体育の導入を図っていた。

2）南校は，英独仏の各課各学年毎日 9 時から 9 時 30 分まで 30 分間の体操を時間割に位置の゙け, この他に課外の体操・散歩も奨励していた。体操 の実施のために，体操教員を採用していたが，そ の教員の多くは, 沼津兵学校附属小学校の体操教 師だった者で，幕末フランス式軍隊体操を習得し た者であったとみられる。したがって，南校で実 施した体操は, 沼津兵学校付属小学校で行ってい たのと同様なフランス式軍隊体操であったと推測 される。

3）開成学校・東京開成学校では体操は, 副科 の扱いだったが,これを重視して，ほとんどの課 程で毎日 9 時半から 10 時まで時間割に配され, 体操教師を附して演習させるもこととしていた。 そして，体操およびその他の授業のために洋服着 用・靴使用の普及が図られた。 
4）開成学校は，1873年 8 月の校舎新築にとも なって体操場の工事を行い, 体操器械の設置を行 った。 その器械は，設計書によって見ると，明ら かにフランス式軍隊体操の器械だった。それは, 『新兵體術教練』以上に詳しい知識を持った者に よる設計だったと見られる。

5）1873年 10 月 9 日「開成学校開業式」に天皇 が臨幸された際, 荻谷・瀧野・福島ら体操教員指 導の下で生徒の体操が天覧されたが，このとき行 われた運動はフランス式軍隊体操の行飛（棒高跳 び）手摺 (平行棒) 矢倉（棚）の三種目であった.

6） 1877 年 1 月から 2 月にかけて東京開成学校 の体操教師が雇止となったが，これは東京大学予 備門生徒は体操伝習所での体操指導に移行するこ とにともなう措置だったと見られる。

7）開成学校・東京開成学校の時代，「榭中体操 法図」の出版，亜鈴の製造，ゴム鞠の修理など体 育書の出版・運動用具の製造・修理などの役割も 担っていた。近代産業の未発達の段階にあっては, 天文方 ·蛮書和解御用 - 洋学所 - 蕃書調所以来の 西洋文化研究センターの系譜を引くものとして西 洋文化導入の機能を拡張せざるを得なかったので ある。

8）第一大学区医学校も体操は副科の扱いだっ たが, その体操場の設置および体操器械の設置に 際しては，第一番中学はこれに協力して，運動場 を実見させ，絵図面の貸し出しを行った。また， 医学校の体操指導を開成学校の体操教師に兼担さ せた。こうして，日本の近代学校に体育を導入す るのに先駆的役割を果たしていた南校の系譜の学 校は, 東校の系譜の学校の体育の導入に大きな援 助を与えていたことが明らかである.

\section{注・文献}

1）今村嘉雄（1967）十九世紀に於ける日本体育の研 究. 不昧堂書店, 東京.

今村嘉雄（1970）日本体育史. 不昧堂出版, 東京. 今村嘉雄（1968）学校体育の父リーランド博士. 不昧堂書店, 東京.

2）岸野雄三・竹之下休蔵（1959）近代日本学校体育 史. 東洋館出版社, 東京.
3）大場一義（1960）西洋体育書の伝来. 蘭学資料研 究会研究報告, 第 66 号; 同 (1962) 田辺良輔の 『仏蘭西軽歩兵程式』一蘭式から仏式へ一, 蘭学資 料研究会研究報告, 第 103 号.

4）能勢修一（1965）明治体育史の研究. 逍遥書院 ; 同（1995）明治期学校体育の研究. 不昧堂出版, 東京.

5）木下秀明（1971）日本体育史研究序説. 不昧堂出 版, 東京.

6）大久保英哲（1996）地方から見た近代体育史上の 歩兵操練・兵式体操 体育・スポーツ史研究展望 一国際的成果と課題一. 不昧堂出版, 東京; 同 （1998）明治期比較地方体育史研究一明治期におけ る石川・岩手県の体操科導入過程一. 不昧堂, 東 京.

7）寺崎昌男（1992）プロムナード東京大学史. 東京 大学出版会, 東京, 9 参照.

8）永田 進（1935）「明治以後の学校体育に関する一 研究」第 6 回体育研究会誌. 体育研究所：pp. 4142.

9）今村嘉雄（1941）榭中体操法図と体操図. 学校体 錬：pp. 1-10, pp. 15-23.

10）今村嘉雄（1951）日本体育史. 不昧堂出版, 東 京: pp. 66-71, p. 77 .

11）今村嘉雄（1967）十九世紀に於ける日本体育の 研究. 不昧堂書店, 東京：pp. 833-840, p. 852.

12）今村嘉雄 (1970) 日本体育史. 不昧堂出版, 東 京: pp. 310-319, pp. 325-326.

13）岸野雄三 - 竹之下休蔵（1959）近代日本学校体 育史. 東洋館出版社：pp. 5-9.

14）渡辺 融（1960）東京大学開設当時における体 育とスポーツに関する一考察。体育学紀要, 東京 大学教養学部体育研究室, 1 号, p. 1 .

15）大場一義（1963）明治初期学校体操の一系譜に ついて. 体育学研究 8 (1) : 95 .

16）能勢修一（1965）明治体育史の研究一体操伝習 所を中心に一, 逍遙書院：pp. 16-22.

17）木下秀明（1971）日本体育史研究序説. 不昧堂 出版, 東京: pp. 28-32.

18）東京帝国大学, 東京（1932）東京帝国大学五十 年史, 上冊. 東京帝国大学, 東京 : pp. 214-232, pp. 891-892，p. 903. (以下「五十年史」と略す.) 19）東京大学百年史編集委員会編（1984）東京大学 百年史 通史 1. 東京大学, 東京：p. 154, p. 180, 
pp. 291-295, pp. 577-578. (以下「百年史」と略 す.)

20）渡辺 融（1960）東京大学開設当時における体 育とスポーツ. 前出：pp. 1-7.

21）東京大学百年史編集委員会編（1984）百年史 通史 1. 東京大学, 東京：pp. 894-911.

22）課外スポーツに関しては，渡辺融（1973）「F.W. ストレンジ考」体育学紀要, 7 号, 東京大学教養学 部体育研究室：7-12 がある.

23）「生徒健康ノ為入校内二運動場取設ケ伺済二付至 急取掛様ノ件」文部省及諸向往復文書 [以下文部 省往復と略す]明治 4 年甲号准允之部 [122]（以下 [ ] 内数字は文書最初の頁を示す), 東京大学大学史史 料室所蔵 (以下略す).

24）含要類纂, 明治 4 年諸向往復, 東京帝国大学五十 年史料（以下五十年史料と略す） 87.2 月 17 日付土 木嗉への督促文には，運動場が設置されないよう では「各国教師へ対し御不体裁八勿論学業之進歩 尹障碍シ…」(強調点筆者) との文言があった. 学 校当局は, 運動場の無いことを近代学校として体 裁悪いことと意識していたのである.

25）同前, 87 .

26）東京帝国大学（1932）五十年史，上冊。東京帝 国大学, 東京：pp. 332-336. しかし,「五十年史 料」および「東京大学史史料室所蔵史料」にはこ のときの運動の天覧を裏付ける史料は発見できな かった。この行幸に関して「省使府県往復簿

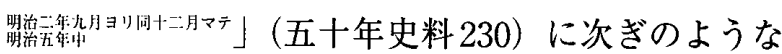
次の文書がある（下線筆者）。

来ル十九日南校

行幸被

仰出候此段相達候也

壬申三月十五日

\section{文部省御中}

追而雨天御延引候毛続書絵図面等

早々二御廻シ可有之侯也

この手続書の提出が遅れていたようであった。こ の手続書が存在し，これを見ることが出来るなら ば，運動天覧があったのか否かが確認できる.

27）「南校へ行幸二条」太政類典，第二編第四十八卷, 儀制三，諸儀式一，p. 74 .

28）東京帝国大学（1932）五十年史，上冊。東京帝 国大学，東京：pp. 214-232.
29）ユネスコ東アジア文化研究センター編（1975） 資料御雇外国人. 小学館, 東京：p. 374, p. 421, p. 464.

30）「本校沿革調書」文部省往復，明治六年甲，雑事 之部 [145].

31）石橋絢彦編（1916）「沼津兵学校沿革」（三）同 方会誌（復刻版 1978年立体社刊）。第 40 号, p. 16.

32）熊井保編（1997）改訂新版 江戸幕臣人名事典. 新人物往来社, 東京： p. 890 .

33）石橋編（1918）同前（八）同前 (同前)，第48号, 47. なお, 大野虎雄は, 沼津兵学校附属小学校の 教育について「学科は素読, 手習, 算術, 地理, 體操，剣術，乗馬，水練，講釈聴聞にて夫ょ‧-.級 より三級まで三段階に分れ，各級毎に教授項目を 指定してある。…體操は休日以外毎日之を課し， 其の時間中日を定めて剣術と乗馬の稽古をなし， $\cdots$. 水練は夏期狩野川又は我入道海岸で行われたが, 剣術と云ひ，乗馬と云ひ，體錬には最も重きを置 いて居た事が分る.」と体育が重視されていたこと を述べている [大野（1943）沼津兵学校附属小学 校, 安川書店, 静岡：p.8.].

34）東京帝国大学（1932）五十年史，上冊。東京帝 国大学：p. 212.

35）「当校生徒教科順序取調ノ件」文部省往復，明治 5 年甲号准允之部 [242].

36）「福島惟成, 苅谷祐之, 瀧野貞豊, 梶田寅太郎体 操教員二雇入八件」文部省往復，明冶六年乙，伺 上申之部 [98］。

37）含要類纂，巻之五拾八，五十年史料 93 .「第…番 中学」構内不要の建家を払下げるに際して学内関 係者に入札案内したとき（明治 6 年 2 月 25 日付） の教職員名中に「体操教師」としてこれら 8 名の名 が記されていた。

38）含要類纂，巻之五拾七，五十年史料 93.

39）同，同，同 93 .

40）東京大学史史料研究会編（1993）東京大学华報, 東京大学出版会, 東京：pp. 1-60. な押, 開成学 校の他に 1874 (明治7）年 12 月設置された東京英 語学校が存在したことを考慮しなければならない。 同校で英語を修めた後開成学校に入学する者が多 く, 同校は事実上開成学校予科の姿をしていたと される。そして，同校の学科課程である下等語学 教則・上等語学教則各 3 学年通じて「体操」が置か れた。同校は，1877 年東京開成学校予科とともに 
東京大学予備門に改められた[教育史編纂会編 （1938）明治以降教育制度発達史，第 1 卷，教育資 料調查会, 東京：pp. 758-770参照].

41）東京大学百年史編集委員会編（1984）百年史 通史 1. 東京大学, 東京：pp. 291-296.

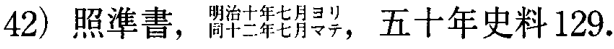

43）東京大学史史料研究会編（1993）東京大学年報 (史料叢書東京大学史). 東京大学出版会, 東京 : p. 11.

44）含要類纂，巻之六拾五，五十年史料 96 .

45）東京開成学校一覧，明治八年二月，五十年史料, p. 36 .

46）同，明治九年，同前，p. 22.

47）「体操所地高低平均ノ件」文部省往復, 明治六年 乙准允之部（築造之部） [46].

48）「体操所土手築立及体操器械之件」文部省往復, 同前 [48].

49）田辺良輔訳（1868）新兵体術教練．岸野雄三監 近代体育文献集成 第 15 巻（復刻版, 日本図書セン 夕ー, 1982 所収), 東京. 25 丁.

50）岸野雄三（1959）近代日本学校体育史. 東洋館 出版社，東京： p. 4.

51）大久保英哲（1993）近代日本体育史における林 正十郎「木馬之書」（推定 1867 年）の意義. 体育学 研究 38 (3) : 157-173.

52）アモロスの体操に関しては, 清水重勇（1986） フランス近代体育史研究序説。不昧堂：p. 69 参照. ヤーンの体操器械に関しては, Jahn, F.L. and Ernst, E. (1816) Die Deutche Turnkunst zur Einrichtung der Turnplatze ; Carl Euler (1885) Friedrich Ludwig Jahns Werke : pp. 157-158. 1816年の原著初版本とも照合した.

53）「明治六年癸酉十月 開成学校開業式二付臨幸之手 続書」含要類纂, 巻六拾（開成学校開業式書類), 五十年史料 93.

54）「天覧体操技術教師並生徒人名」, 同前.

55）東京開成学校「人員調查表」明治 8 年 12 月およ び同 9 年 1 月〜同 9 年 12 月 [514]，文部省往復，明 治 9 年甲，[497］および [500] 〜 [514].

56）「加藤市次郎，津金胤全雇入八件」同前，同前
[252].

57）東京英語学校年報（明治 8 年分)，文部省第 4 年 報：pp. 560-564.

58）含要類纂，巻之七拾（明治 8 年), 本省開申之部, 五十年史料 98 .

59）「加藤市次郎，津金片全解雇ノ件」同前，明治 10 年甲 $[553]$.

60）「滝野貞豊解雇ノ件」同前，同前 [552].

61）「本校蔵版ノ分准刻課へ進達ノ件」同前, 明治7 年上申之部 [370].

62）「本校蔵版図法階梯並体操図ノ件」同前, 同前雑 事「345」.

63）「大阪師範学校ヨリ本校体操法図請求ノ件」同前, 同前雑事 [432].

64）「筋骨運動器械製造ノ件」同前, 学務課之部, 庶 務往復ノ件 [348].

65）含要類纂, 巻之上, 明治 9 諸向往復, 五十年史料 $100-1$.

66）含要類纂, 巻八十九, 諸向往復之部, 明治十年 分甲。五十年史料 103.

$67 ）$ 諸達控，明治 5 年 7 月 6 年 12 月迄，五十年史料 143.

68）東京帝国大学（1932）東京帝国大学五十年史, 上冊。東京帝国大学，東京：p. 392 .

69）営縓伺済，明治 6 年中，五十年史料 208 .

70）東京帝国大学（1932）東京帝国大学五十年史, 上冊。東京帝国大学，東京：pp. 393-406 および東 京医学校（明治 6 年一同 9 年）東京大学年報 第 1 卷 所収. 前出，東京：pp. 174-181.

71）含要類纂，巻之五拾八，五十年史料 93 .

72）本省達，明治 6 年 1 月より 5 月二至ル，同前 186.

73）用度伺，明治 5 年 1 月ヨリ 6 年 12 月マテ，同前 222.

74）本省願伺届諸学校掛合，明治6 年，同前 206 .

75）含要類纂, 巻之五拾八, 同前 93.

76）諸達控，明治 5 年 7 月一 6 年 12 月迄，同前 143 .

77）同前，同前，同前.

平成 15 年 1 月 10 日受付 平成 15 年 5 月 31 日受理 